\title{
Pengolahan Tepung Sagu dengan Fermentasi Aerobik Menggunakan Rhizopus sp.
}

\author{
Claudya Patricia Caesy, Christa Kathleen Sitania, Setiyo Gunawan, dan Hakun Wirawasista \\ Aparamarta \\ Departemen Teknik Kimia, Fakultas Teknologi Industri, Institut Teknologi Sepuluh Nopember (ITS) \\ e-mail: gunawan@chem-eng.its.ac.id
}

\begin{abstract}
Abstrak-Tepung sagu dapat digunakan sebagai salah satu alternatif untuk mensubsitusi kebutuhan tepung terigu di Indonesia. Hal ini didorong oleh kebutuhan tepung terigu yang semakin tinggi dalam industri pangan. Sementara itu, untuk memenuhi kebutuhan tersebut Indonesia harus mengimpor gandum yang tidak dapat diproduksi di dalam negeri. Sehingga menimbulkan ketergantungan komoditi pangan terhadap negara lain. Sagu dipilih karena Indonesia memiliki hutan sagu terluas di dunia yakni seluas 1,2 juta hektar (ha) atau setara dengan $52 \%$ dari areal sagu dunia. Berdasarkan hasil uji proksimat, kandungan protein tepung sagu adalah 1,11\%, sedangkan protein tepung sagu yang difermentasi meningkat sebanyak lima sampai delapan kali. Menurut S NI 3751:2009, komposisi proksimat tepung terigu memiliki kadar protein minimal 7,0\%, kadar air maksimal 14,5\%, dan kadar abu maksimal $0,6 \%$. Sedangkan, proksimat sagu setelah fermentasi secara aerob memiliki kadar protein $8,0 \%$, kadar air $13,41 \%$, dan kadar abu $0,35 \%$. Sehingga berdasarkan data komposisi proksimat tersebut, tepung sagu memiliki potensi untuk menjadi alternatif tepung terigu, baik sebagai bahan subsitusi maupun bahan yang digunakan bersamaan dengan tepung terigu dalam pembuatan berbagai macam pengolahan pangan. Pabrik sagu ini akan didirikan di Kabupaten Indragiri Hilir, Provinsi Riau. Riau merupakan daerah penghasil sagu terbanyak di Indonesia dengan angka produksi mencapai 246.000 ton per tahun. Proses pembuatan tepung sagu dengan proses fermentasi dibagi menjadi 3 tahapan, yaitu tahap pengolahan bahan baku, fermentasi, dan pengolahan produk. Pabrik pengolahan tepung sagu ini direncanakan beroperasi secara semi-kontinyu selama 24 jam dengan waktu produksi 330 hari/tahun. Berdasarkan analisa ekonomi yang telah dilakukan diperoleh internal rate of return sebesar $31 \%$ dengan pay out time selama 3,39 tahun dan break even point sebesar $\mathbf{2 1 , 5 4 \%}$. Ditinjau dari uraian di atas, maka secara teknis dan ekonomis, pabrik pengolahan tepung sagu layak untuk didirikan.
\end{abstract}

Kata Kunci-Sagu, Fermentasi, Aerobik, Industri pangan.

\section{PENDAHULUAN}

$\mathrm{T}_{\mathrm{d}}^{\mathrm{B}}$ EPUNG terigu sangat di butuhkan dalam industri pangan di Indonesia. Untuk memenuhi kebutuhan tersebut Indonesia harus mengimpor gandum yang tidak dapat diproduksi di dalam negeri. Namun, semakin hari penggunaan tepung terigu semakin meningkat dengan makin banyaknya industri pangan yang produknya berbahan dasar tepung terigu. Sepanjang tahun 2014, konsumsi tepung terigu mengalami peningkatan sekitar 5,09\% dibandingkan pada tahun 2013. Saat ini impor tepung terigu Indonesia mencapai 197.000 ton untuk memenuhi kebutuhan nasional. Untuk mengurangi ketergantungan terhadap tepung terigu, maka tepung terigu perlu disubsitusi dengan tepung lain.

Upaya mensubstitusi tepung terigu dengan tepung dari bahan baku lokal sebagai alternatif merupakan tantangan sekaligus peluang untuk pengembangan produk lokal. Salah satu bahan pangan lokal yang dapat dijadikan sebagai bahan alternatif yang menjanjikan adalah sagu. Hal tersebut dikarenakan Indonesia memiliki hutan sagu terluas di dunia yakni seluas 1,2 juta hektar (ha) atau setara dengan 52\% dari areal sagu dunia. Selain itu tanaman sagu juga dapat dibudidayakan dengan mudah dan tidak membutuhkan perlakuan khusus karena memiliki kemampuan tumbuh di lahan marginal. Dengan demikian, tanaman sagu menjadi salah satu sumber pati andalan pada masa mendatang [1].

Meskipun tanaman sagu mempunyai potensi yang cukup besar sebagai bahan pangan, namun pemanfaatannya belum berkembang dengan maksimal. Hal tersebut berkaitan dengan pengolahan pasca panen sagu masih dilakukan secara tradisional, industri modern yang mengekstrak pati sagu masih sedikit. Berdasarkan data Perhimpunan Pendayagunaan Sagu Indonesia (PPSI), produksi sagu nasional saat ini baru mencapai 400.000 ton per tahun atau sekitar $8 \%$ dari potensi sagu nasional. Dari jumlah produksi tersebut, hampir separuhnya dihasilkan dari Provinsi Riau, sementara separuh lainnya berasal dari daerah Papua, Maluku, dan lainnya [2].

Berdasarkan hasil uji proksimat, kandungan protein pati sagu alami adalah $1,11 \%$, sedangkan bahan pati sagu yang dibuat dengan menggunakan prinsip modifikasi secara fermentasi memperlihatkan peningkatan kandungan nilai proteinnya sebanyak lima sampai delapan kali. Kandungan karbohidrat, lemak, dan kadar abu berkurang pada sagu yang telah difermentasi. Sebaliknya, kadar air dan serat kasar meningkat [3].

Menurut Standar Nasional Indonesia (SNI) 3751:2009, komposisi proksimat tepung terigu antara lain memiliki kadar 
protein minimal 7,0\%, kadar air maksimal 14,5\%, dan kadar abu maksimal $0,6 \%$. Sedangkan, proksimat sagu setelah fermentasi secara aerob antara lain memiliki kadar protein 8,0\%, kadar air $13,41 \%$, dan kadar abu $0,35 \%$. Sehingga berdasarkan data komposisi proksimat tersebut, tepung sagu memiliki potensi untuk digunakan sebagai alternatif untuk mengurangi peran tepung terigu, baik sebagai bahan subsitusi maupun bahan yang digunakan bersamaan dengan tepung terigu dalam pembuatan berbagai macam pengolahan pangan [4].

Tepung sagu selama ini diproduksi secara konvensional oleh industri rumahan, sehingga pemanfaatan sagu sebagai bahan baku tepung kurang maksimal. Maka dari itu, perlu dikembangkan proses produksi tepung sagu secara komersial skala besar agar dapat mencukupi kebutuhan pasar. Selain itu, proses modifikasi sagu perlu dilakukan agar sagu memiliki kadar protein tinggi dan memiliki sifat fisiko-kimia mendekati tepung terigu. Sehingga dengan adanya pabrik tepung sagu ini, diharapkan dapat mencukupi kebutuhan nasional serta mengurangi jumlah impor bahan makanan pokok yang cenderung meningkat setiap tahunnya.

\section{SELEKSI DAN URAIAN PROSES}

Tepung sagu yang ada di Indonesia saat ini umumnya diproduksi secara konvensional menggunakan peralatan yang kurang memadai. Hal tersebut menghasilkan produk dengan kapasitas yang kecil serta kualitas yang rendah. Untuk memenuhi kebutuhan nasional, maka tepung sagu mulai diproduksi pada skala industri dengan menggunakan peralatan modern. Sebagai contoh adalah penyaringan yang sebelumnya menggunakan kain, pada pabrik ini menggunakan rotary vacuum drum filter. Contoh lain adalah proses pengeringan yang sebelumnya hanya dijemur dibawah sinar matahari, pada pabrik ini proses pengeringan menggunakan flash dryer Namun demikian, tepung sagu yang dihasilkan tersebut umumnya memiliki kandungan protein yang rendah, yaitu sekitar $1,11 \%$. Sedangkan agar dapat menjadi bahan pangan pengganti tepung terigu, batas minimal kandungan proteinnya adalah 7\%. Oleh karena itu, untuk menaikkan kadar protein tepung sagu maka dilakukan proses fermentasi. [3]

Fermentasi merupakan suatu cara untuk mengubah substrat menjadi produk tertentu yang dikehendaki dengan menggunakan bantuan mikroba. Proses fermentasi mempunyai kelebihan, antara lain tidak mempunyai efek samping yang negatif, mudah dilakukan, relatif tidak membutuhkan peralatan khusus dan biayanya murah. [5]

Berdasarkan penelitian yang telah dilakukan, pembuatan tepung sagu dengan fermentasi ini dapat dilakukan dengan menggunakan dua metode, yaitu metode fermentasi aerob dan metode fermentasi anaerob. Pemanfaatan Rhizopus sp. sebagai bahan pembiakan awal dalam proses fermentasi ini dirasa paling cocok dan sesuai dengan tujuan fermentasi, yaitu untuk meningkatkan kadar proteinnya [3].
Tabel 1.

Data Analisis Tepung Sagu Tanpa Fermentasi

\begin{tabular}{ccc}
\hline \hline No & Parameter & Hasil Analisa (\%) \\
\hline 1 & Protein & 1,11 \\
2 & Karbohidrat & 84,03 \\
3 & Lemak & 0,27 \\
4 & Kadar Air & 13,90 \\
5 & Kadar Abu & 0,41 \\
6 & Serat Kasar & 0,27 \\
& & \\
\hline \hline
\end{tabular}

\section{A. Metode Fermentasi Aerob}

Fermentasi aerob adalah jenis fermentasi yang memerlukan adanya oksigen. Berikut ini adalah hasil analisis kadar proksimat tepung sagu dengan fermentasi aerob :

Tabel 2.

Data Analisis Tepung Sagu dengan Fermentasi Aerob

\begin{tabular}{ccc}
\hline \hline No & Parameter & Hasil Analisa (\%) \\
\hline 1 & Protein & 8,00 \\
2 & Karbohidrat & 77,84 \\
3 & Lemak & 0,09 \\
4 & Kadar Air & 13,41 \\
5 & Kadar Abu & 0,35 \\
6 & Serat Kasar & 0,31 \\
& & \\
\hline \hline
\end{tabular}

Fermentasi dengan fungi (kapang) umumnya bersifat aerob, karena semua kapang bersifat aerobik, yaitu membutuhkan udara untuk pertumbuhannya. Fermentasi aerob ini bertujuan untuk memproduksi sel kapang dan enzim hidrolis is. [6]

\section{B. Metode Fermentasi Anaerob}

Fermentasi anaerob adalah jenis fermentasi yang tidak memerlukan adanya oksigen. Berikut ini adalah hasil analisis kadar proksimat tepung sagu dengan fermentasi anaerob :

Tabel 3.

Data Analisis Tepung Sagu dengan Fermentasi Anaerob

\begin{tabular}{ccc}
\hline \hline No & Parameter & Hasil Analisa (\%) \\
\hline 1 & Protein & 5,70 \\
2 & Karbohidrat & 75,68 \\
3 & Lemak & 0,13 \\
4 & Kadar Air & 17,41 \\
5 & Kadar Abu & 0,21 \\
6 & Serat Kasar & 0,87 \\
& & \\
\hline \hline
\end{tabular}

Fermentasi anaerobik berguna untuk menghambat pertumbuhan kapang, tetapi membiarkan enzim yang telah terbentuk untuk tetap berfungsi. [6]

Hasil fermentasi secara aerob selama 10 hari, tepung sagu mengalami peningkatan protein yang lebih tinggi dibandingkan dengan tepung sagu yang difermentasi secara anaerob. Untuk kandungan karbohidrat, sagu yang difermentasi secara anaerob menunjukkan hasil yang lebih sedikit dibandingkan dengan tepung sagu yang difermentasi secara aerob. Kenaikan kadar protein pada tepung sagu diakibatkan oleh penambahan 
protein yang diperoleh dari perubahan nitrogen inorganik menjadi protein sel selama pertumbuhan mikroba. Makin subur pertumbuhan mikroba makin tinggi pula kadar proteinnya karena sebagian besar sel mikroba merupakan protein [7]

Sedangkan penurunan nilai kandungan karbohidrat setelah fermentasi diduga karena adanya pemanfaatan mikroba akan serat kasar untuk pertumbuhannya [8].

Hal ini disebabkan oleh adanya aktivitas enzim lignoselulotik dimana enzim ini dapat memecah ikatan lignin dengan selulosa, ikatan lignin dengan hemiselulosa serta ikatan lignin dengan protein. Dengan pecahnya ikatan lignin tersebut maka secara langsung akan berakibat terhadap penurunan kadar serat kasar pada sagu. [9]

Uji kadar lemak untuk sagu baik secara fermentasi aerob maupun anaerob juga mengalami penurunan. Hal ini diduga bahwa dalam pertumbuhannya mikroba pun memanfaatkan lemak dalam bahan tepung sagu untuk menghasilkan enzim lipase. Medwid and Grand (1994) menyatakan bahwa beberapa reaksi katalis oleh enzim lipase menyebahkan produk fermentasi yang dihasilkan memiliki kandungan kadar lemak yang lebih sedikit.

Sagu yang difermentasi baik secara aerob maupun anaerob menghasilkan kadar abu yang lebih sedikit yaitu $0,21 \%$, namun kadar air malah mengalami kenaikan yaitu $17,41 \%$. Hal ini disebabkan adanya pemecahan glukosa dan pati menjadi asam laktat [10]. Berikut standarisasi tepung terigu dalam pangan :

Tabel 4.

Standarisasi Tepung Terigu dalam Pangan

\begin{tabular}{ccc}
\hline \hline Jenis Uji & Satuan & Persyaratan \\
\hline Air & $\%, \mathrm{~b} / \mathrm{b}$ & Maksimal 14,5\% \\
Abu & $\%, \mathrm{~b} / \mathrm{b}$ & Maksimal 0,6\% \\
Protein & $\%, \mathrm{~b} / \mathrm{b}$ & Minimal 7,0\% \\
& & \\
\hline \hline
\end{tabular}

Dari data faktor-faktor yang menjadi pertimbangan dalam pemilihan proses pembuatan tepung sagu di pabrik ini, maka fermentasi secara aerob dapat digunakan. Hal ini dikarenakan kandungan proksimat pada tepung sagu hasil fermentasi secara aerob lebih memenuhi standar tepung terigu, yaitu protein $8,00 \%$, kadar air $13,41 \%$, dan kadar abu 0,35 .

\section{MATERIAL BALANCE}

Berikut merupakan hasil perhitungan dari material balance pabrik pengolahan tepung sagu ini dimana kapasitas feed sebesar $17.677 \mathrm{~kg} / \mathrm{jam}$ dan kapasitas produk yang dihasilkan adalah sebesar $11.364 \mathrm{~kg} / \mathrm{jam}$.

\section{ANALISA EKONOMI}

Pabrik ini direncanakan memiliki 169 pekerja dengan komposisi modal $40 \%$ modal sendiri dan $60 \%$ modal pinjaman dan bunga bank $10.5 \%$. Dari hasil perhitungan pada neraca ekonomi didapatkan Total Capital Investment pabrik ini sebesar Rp 309. 971. 689. 372. Selain itu, diperoleh IRR sebesar $31 \%$ dan BEP 21,54\% dimana pengembalian modalnya adalah selama 3.39 tahun. Umur pabrik ini diperkirakan adalah selama 10 tahun dengan masa periode pembangunannya selama 2 tahun di mana operasi pabrik ini adalah 330 hari/tahun.

\section{KESIMPULAN/RINGKASAN}

Ditinjau dari berbagai hal di atas, maka pabrik pengolahan tepung sagu yang berlokasi di Kabupaten Indragiri Hilir, Provinsi Riau dinyatakan layak untuk didirikan dikarenakan Interest rate of return dari pabrik lebih besar dari pada bunga bank serta Pay Out Time pada pabrik ini kurang dari 5 tahun.

\section{UCAPAN TERIMA KASIH}

Kami ucapan terima kasih kepada Bapak Setiyo Gunawan dan Bapak Hakun Wirawasista selaku dosen pembimbing kami atas bimbingan, ilmu serta semangat yang diberikan kepada kami. Kami ucapkan terima kasih pula untuk teman-teman teknologi biokimia atas dukungan yang telah diberikan selama ini.

\section{DAFTAR PUSTAKA}

[1] B. P. dan P. T. (BPPT), "Modifikasi Tepung Sagu dengan Cara Ekstrusi menjadi Sagu Flakes untuk Substitusi Tepung Terigu sebagai Bahan Baku Industri Pangan Olahan Kapasitas 1 Ton/Hari di Provinsi Bangka Belitung dan Lampung," 2014.

[2] S. Rumaru, "Sagu, Komoditas Pangan Strategis Masa Depan," 2011.

[3] C. Wuniarto, E., Sampekalo, J., Lumenta, "Analysis of sago starch fermented with aerobic and anaerobic processes as alternative material for fish meal," Aquat. Sci. Manag., vol. 2, no. 2, pp. 35-37, 2014.

[4] B. S. N. (BSN), "Tepung terigu sebagai bahan makanan," sisni.bsn.go.id, 2017. .

[5] M. Iskandar, B and Tampoebolon, "Kajian perbedaan aras dan lama perendaman fermentasi ampas sagu dengan Aspergillus niger terhadap kandungan protein kasar dan serat kasar," in Seminar Nasional Kebangkitan Peternakan, Fakultas Peternakan, 2009.

[6] S. Fardiaz, Mikrobiologi Pangan. Gramedia Pustaka Utama, 1992.

[7] A. Habibi, "Pengaruh berbagai dosis ragi dan dosis pakan berupa dedak fermentasi terhadap pertumbuhan ikan bandeng (Chanos chanos Forskal)," Universitas Muhammadiyah, 2008.

[8] Y. I. Widjastuti, T., Abun., T. W., dan Asmara, "Pengolahan Bungkil Inti Sawit Melalui Fermentasi oleh Jamur Marasmius sp. Guna Menunjang Bahan Pakan Alternatif untuk Ransum Ayam Broiler," 2007.

[9] dan B. Purwadaria, T., Sinurat, A. P., Dupriyati, H., Hamid, "Evaluasi nilai gizi lumpur sawit fermentasi dengan Aspergillus niger setelah proses pengeringan dengan pemanasan," Ilmu Ternak dan Vet., vol. 4, no. 4, pp. 257-263, 2002.

[10] dan M. Azizah, N., Al Baarri, S., "Pengaruh lama fermentasi terhadap kadar alkohol, $\mathrm{pH}$, dan produksi gas pada proses fermentasi bioethanol dari whey dengan substitusi kulit nanas," J. Penelit. Fak. Peternak. dan Pertan., vol. 1, no. 2, pp. 7277, 2012. 